(c) American Dairy Science Association, 2005.

\title{
Effect of Increasing Energy and Protein Intake on Body Growth and Carcass Composition of Heifer Calves*
}

\author{
E. G. Brown, ${ }^{1}$ M. J. VandeHaar, ${ }^{1}$ K. M. Daniels, ${ }^{1}$ J. S. Liesman, ${ }^{1}$ L. T. Chapin, ${ }^{1}$ \\ D. H. Keisler, ${ }^{2}$ and M. S. Weber Nielsen ${ }^{1}$ \\ ${ }^{1}$ Department of Animal Science, Michigan State University, East Lansing 48824 \\ ${ }^{2}$ Department of Animal Sciences, University of Missouri, Columbia 65211-5300
}

\begin{abstract}
The objective was to determine whether increased energy and protein intake between 2 and 14 wk of age would increase growth rates of heifer calves without fattening. At 2 wk of age, Holstein heifer calves were assigned to 1 of 4 treatments in a $2 \times 2$ factorial arrangement with 2 levels of protein and energy intake (moderate $[\mathrm{M}]$; high $[\mathrm{H}]$ ) in period 1 (2 to $8 \mathrm{wk}$ of age) by 2 levels of protein and energy intake (low [L]; high $[\mathrm{H}]$ ) in period 2 ( 8 to $14 \mathrm{wk}$ of age) to produce similar initial BW for all 4 treatments. Treatments were $\mathrm{ML}, \mathrm{MH}$, $\mathrm{HL}$, and $\mathrm{HH}$, indicating moderate or high energy and protein intake during the first period and low or high intake during the second period. The $\mathrm{M}$ diet consisted of a standard milk replacer $(21.3 \% \mathrm{CP}, 21.3 \%$ fat $)$ fed at $1.1 \%$ of $\mathrm{BW}$ on a $\mathrm{DM}$ basis and a $16.5 \% \mathrm{CP}$ grain mix fed at restricted intake to promote $400 \mathrm{~g}$ of average daily gain (ADG), whereas the L diet consisted only of the grain mix. The $\mathrm{H}$ diet consisted of a high-protein milk replacer $(30.3 \% \mathrm{CP}, 15.9 \%$ fat) fed at $2 \%$ of $\mathrm{BW}$ on a DM basis and a $21.3 \%$ CP grain mix available ad libitum. Calves were weaned gradually from milk replacer by $7 \mathrm{wk}$ and slaughtered at $8(\mathrm{n}=11)$ or 14 wk of age $(n=41)$. In periods 1 and 2 , ADG and the gain:feed ratio were greater for calves fed the $\mathrm{H}$ diet. Calves fed the $\mathrm{H}$ diet were taller after both periods 1 and 2 . No difference was observed in carcass composition at $8 \mathrm{wk}$, but at 14 wk calves fed $\mathrm{MH}$ and $\mathrm{HH}$ had less water and more fat than calves fed ML and HL. Plasma IGF-I concentrations were greatest for calves fed the $\mathrm{H}$ diet during either period. Plasma leptin concentrations were increased in calves fed the $\mathrm{H}$ diet during period 1 from 4 to $6 \mathrm{wk}$ of age. Increasing energy and protein intake from 2 to $8 \mathrm{wk}$ and 8 to $14 \mathrm{wk}$ of age increased $\mathrm{BW}$, withers height, and gain:feed ratio. Calves fed the
\end{abstract}

Received May 26, 2004.

Accepted September 27, 2004.

Corresponding author: M. S. Weber Nielsen; e-mail: msw@ msu.edu.

*Supported by the Michigan Corn Growers Association and the Corn Marketing Program of Michigan.
$\mathrm{H}$ diet from 8 to 14 wk of age had more body fat than calves fed the L diet. Increased energy and protein intake can increase the rate of body growth of heifer calves and potentially reduce rearing costs.

(Key words: heifer, calf, growth, carcass composition)

Abbreviation key: ADG = average daily gain, $\mathbf{H}=$ high protein and energy intake, $\mathbf{L}=$ low protein and energy intake, $\mathbf{M}=$ moderate protein and energy intake.

\section{INTRODUCTION}

Costs of raising replacement heifers account for approximately $20 \%$ of dairy farm expenses (Heinrichs, 1993). One possible way to decrease this cost is to calve heifers at a younger age. To decrease age at first calving, heifers can be fed for accelerated growth rates prior to puberty and bred at an earlier age. It is possible to raise heifers to a desirable BW at first calving $(600 \mathrm{~kg}$; Heinrichs, 1993) as early as 19 to 20 mo of age using this strategy. However, high-energy diets allowing rapid BW gain and excess fattening from approximately 3 to 10 mo of age have been shown to impair mammary development (Sejrsen and Purup, 1997). Using younger heifers, others (Foldager and Krohn, 1994; Bar-Peled et al., 1997) found that increased intake of whole milk in heifer calves before 2 mo of age had no negative effects on subsequent milk production. No studies have been performed on heifers $<3$ mo of age to evaluate the effects of accelerated growth as a result of increased intake of milk replacer. By decreasing age at first calving, the potential exists to increase lifetime profitability, but negative effects caused by accelerated growth, such as excess fattening, must be avoided.

Dairy heifer calves may have the potential for faster growth than that typically occurring on most farms without excessive accumulation of body fat. With respect to composition of diet, Donnelly and Hutton (1976) demonstrated that a higher-protein milk replacer fed to bull calves increased carcass protein while reducing carcass fat content. Diaz et al. (2001) observed a similar effect that was more pronounced, possibly because of 
increased mature size of Holsteins and potential for lean growth compared with those $30 \mathrm{yr}$ ago. In addition, Blome et al. (2003) demonstrated that carcass protein increased and fat decreased as the ratio of protein to energy increased in diets of bull calves fed for average daily gain (ADG) of up to $0.62 \mathrm{~kg} / \mathrm{d}$. Data from Bartlett (2001) showed a similar effect of increasing dietary CP concentration when dietary $\mathrm{CP}$ was not limiting. On the other hand, increasing the fat content in milk replacer fed to bull calves in an isocaloric, isonitrogenous diet increased carcass fat percentage without altering carcass protein (Tikofsky et al., 2001). With respect to amount fed, increasing the intake of milk replacer DM from 1.25 to $2.25 \%$ of $\mathrm{BW}$ increased $\mathrm{ADG}$ while altering carcass composition of bull calves (Bartlett, 2001). Body fat percentage increased with feeding rate, although the actual composition of BW gain as fat was not affected. Similarly, Diaz et al. (2001) reported that body fat percentage of calves increased in calves slaughtered at 105 vs. $65 \mathrm{~kg}$ of BW. Currently, interpretation of the potential benefits or drawbacks of such changes in carcass composition of heifer calves is limited by our lack of knowledge of their impact on future growth and productivity. Thus, it is relevant to investigate the effects of increased protein and energy intake on body growth and composition.

This experiment was designed to determine whether feeding a high-protein, low-fat milk replacer and high protein grain mix would increase growth without fattening in heifer calves from 2 to $14 \mathrm{wk}$ of age. Treatment effects on mammary development in calves in this experiment are reported in a companion paper (Brown et al., 2005).

\section{MATERIALS AND METHODS}

\section{Animals and Treatments}

Female Holstein calves $(\mathrm{n}=74 ; 43.8 \pm 3 \mathrm{~kg})$ were blocked by date of purchase. Calves were purchased from an agent in Indiana (blocks 1 and 2; n = 15 and 20 calves, respectively) or from Michigan dairy farms (blocks 3 and 4; $\mathrm{n}=19$ and 20 calves, respectively). Criteria for purchase of heifer calves were that they must have Holstein color markings, be 5 to $10 \mathrm{~d}$ of age, and weigh $>45 \mathrm{~kg}$ to minimize the likelihood of freemartins. The calves arrived at the Michigan State University Dairy Cattle Teaching and Research Center in February, March, April, and May 2001. Upon arrival, calves were weighed and housed either in individual pens or hutches. Calves received injections 2 to $72 \mathrm{~h}$ after arrival of $3 \mathrm{~mL}$ of Bo-Se $(1 \mathrm{mg}$ of selenium, 50 $\mathrm{mg}$ (68 IU) of vitamin E/mL; Schering Plough Animal Health Corp., Union, $\mathrm{NJ}$ ) and $1 \mathrm{~mL}$ of vitamin A (500,000 IU/mL) and D (75,000 IU/mL; Vedco, Inc., St.
Joseph, MO). At the same time, calves were vaccinated against infectious bovine rhinotracheitis virus and parainfluenza type 3 intranasally with $2 \mathrm{~mL}$ of TSV-2 (Pfizer Animal Health, New York, NY); against multiple gram-negative endotoxemic diseases with $2 \mathrm{~mL}$ of Endovac-Bovi (Immvac, Inc., Columbia, MO); against Pasteurella haemolytica, P. multocida, and Haemophilus somnus with $1 \mathrm{~mL}$ of Nuflor/13.6 kg of BW (Schering-Plough Animal Health Corp.); and against Clostridium perfringens types $\mathrm{B}, \mathrm{C}$, and $\mathrm{D}$ plus tetanus with 5 $\mathrm{mL}$ of Bar Vac CD/T-Toxoid (Boehringer Ingelheim, St. Louis, MO).

The day following arrival, calves began a 1-wk adaptation period with feedings of $1.9 \mathrm{~L}$ of milk replacer (21.3\% CP, $21.3 \%$ fat; reconstituted at $11.8 \% \mathrm{DM})$ at 0700 and $1700 \mathrm{~h}$ (Table 1). Calves had water available ad libitum and were fed daily $100 \mathrm{~g}$ of calf starter $(20.5 \%$ CP; Gold Flake Calf Starter, Nutrena Feeds-Cargill, Inc., Minneapolis, MN) beginning on the third day after arrival. Fecal scores $(1=$ dry, hard; $2=$ soft, formed; $3=$ pudding-like; $4=$ mixture of liquid and solids; $5=$ liquid) were assessed twice daily during the first $21 \mathrm{~d}$ after calves arrived at the research center. No differences in pretreatment fecal scores were detected. Calves were fed milk replacer using an esophageal feeder when they did not consume any milk replacer after 2 consecutive feedings or were determined to be sick (body temperature $>39^{\circ} \mathrm{C}$ ), rapidly breathing, or lethargic in appearance.

Twenty-two calves were dropped from the experiment: 6 calves from block 1; 10 from block 2; 5 from block 3; and 1 from block 4 . Eight calves died during the 1 -wk adaptation period, and 10 calves died during period 1 ( 5 per treatment). In addition, 3 calves during period 1 were removed for health problems of viral or bacterial origin ( 1 on the $\mathbf{M}$ [moderate protein and energy intake] diet and 2 on the $\mathbf{H}$ [high protein and energy intake] diet). The calves purchased for blocks 1 and 2 from an out-of-state source had a greater mortality rate (14 of 35) than calves purchased for blocks 3 and 4 from an in-state source (4 of 39). One calf was removed after the end of the experiment when determined to be a freemartin. A total of 52 calves remained on the study $(9,10,14$, and 19 calves in blocks 1 through 4 , respectively).

Following the 1-wk adaptation period, calves were assigned randomly to 1 of 4 treatments in a $2 \times 2$ factorial arrangement to produce similar $\mathrm{BW}$ among treatments. Withers height was not different among treatments at the start of the experiment.

From 2 to 8 wk of age (period 1), the M diet (Table 1) consisted of standard milk replacer (Calvita Supreme; Milk Specialties Company, Dundee, IL; 21.3\% CP, $21.3 \%$ fat, $4.7 \mathrm{kcal}$ of ME/g of DM; Table 2) fed on a 
Table 1. Experimental diets.

\begin{tabular}{|c|c|c|c|c|}
\hline \multirow[t]{2}{*}{ Treatment and age } & \multicolumn{4}{|c|}{ Experimental $\operatorname{diet}^{1}$} \\
\hline & ML & $\mathrm{MH}$ & HL & $\mathrm{HH}$ \\
\hline Adaptation period ( 1 to $2 \mathrm{wk}$ of age) & \multicolumn{4}{|c|}{$450 \mathrm{~g} / \mathrm{d}$ standard milk replacer and up to $100 \mathrm{~g} / \mathrm{d}$ of standard calf starter } \\
\hline \multicolumn{5}{|l|}{ Period 2} \\
\hline 8 to 9 wk of age & $\begin{array}{l}\text { Standard calf starter } \\
\text { fed at restricted intake } \\
\text { for ADG of } 0.4 \mathrm{~kg} / \mathrm{d}\end{array}$ & $\begin{array}{l}\text { High protein calf } \\
\text { starter fed for ad } \\
\text { libitum intake }\end{array}$ & $\begin{array}{l}\text { Standard calf starter } \\
\text { fed at restricted } \\
\text { intake for ADG of } \\
0.4 \mathrm{~kg} / \mathrm{d}\end{array}$ & $\begin{array}{l}\text { High protein calf } \\
\text { starter fed for ad } \\
\text { libitum intake }\end{array}$ \\
\hline 9 to 14 wk of age & $\begin{array}{l}3.5 \mathrm{kcal} \mathrm{ME} / \mathrm{g} \\
17 \% \mathrm{CP}\end{array}$ & $\begin{array}{l}3.6 \mathrm{kcal} \mathrm{ME} / \mathrm{g} \\
20 \% \mathrm{CP}\end{array}$ & $\begin{array}{l}3.5 \mathrm{kcal} \mathrm{ME} / \mathrm{g} \\
17 \% \mathrm{CP}\end{array}$ & $\begin{array}{l}3.6 \mathrm{kcal} \mathrm{ME} / \mathrm{g} \\
20 \% \mathrm{CP}\end{array}$ \\
\hline
\end{tabular}

${ }^{1} \mathrm{ML}=$ Moderate (M; moderate protein and energy intake) diet from 2 to 8 wk followed by low (L; low protein and energy intake) diet from 8 to $14 \mathrm{wk}, \mathrm{MH}=\mathrm{M}$ diet followed by high $(\mathrm{H}$; high protein and energy intake) diet, $\mathrm{HL}=\mathrm{H}$ diet followed by $\mathrm{L}$ diet, and $\mathrm{HH}=\mathrm{H}$ diet followed by $\mathrm{H}$ diet. Composition of feeds is listed in Tables 2 and 3.

DM basis at $1.1 \%$ of BW (reconstituted to $11.8 \% \mathrm{DM}$ ) and standard starter grain (20.5\% CP; Gold Flake Calf Starter; Nutrena Feeds-Cargill, Inc.; Table 3) fed at restricted intake to achieve $0.4 \mathrm{~kg} / \mathrm{d}$ of ADG from 2 to 8 wk of age. The $\mathrm{H}$ diet consisted of a high-protein milk replacer (Excelerate; Milk Specialties Company, Dundee, IL; $30.3 \% \mathrm{CP}, 15.9 \%$ fat, $4.4 \mathrm{kcal}$ of ME/g of DM; Table 2 ) fed on a DM basis at $2 \%$ of BW (reconstituted to $14.1 \% \mathrm{DM})$ and high-protein starter grain $(25.0 \%$

Table 2. Milk replacer composition on a DM basis. ${ }^{1}$

\begin{tabular}{lcc}
\hline Variable & $\begin{array}{l}\text { Moderate (M) } \\
\text { diet }^{2}\end{array}$ & $\begin{array}{l}\text { High } \\
\text { diet }^{3}\end{array}$ \\
\hline CP, \% & 21.3 & 30.3 \\
Crude fat, \% & 21.3 & 15.9 \\
Crude fiber, \% & 0.16 & 0.16 \\
Ca minimum, \% & 0.79 & 0.79 \\
Ca maximum, \% & 1.33 & 1.33 \\
P, \% & 0.74 & 0.64 \\
Vitamin A, IU/kg & 66,150 & 165,375 \\
Vitamin D3, IU/kg & 22,050 & 5,513 \\
Vitamin E, IU/kg & 441 & 110 \\
\hline
\end{tabular}

${ }^{1}$ Feed manufacturer's guaranteed analysis.

${ }^{2}$ Calvita Supreme (Milk Specialties Company, Dundee, IL); M = moderate protein and energy intake.

${ }^{3}$ Excelerate (Milk Specialties Company); $\mathrm{H}$ = high protein and energy intake.
CP; Herd Builder Calf Starter; Nutrena Feeds-Cargill, Inc.; Table 3) fed ad libitum. Milk replacer was prepared by adding powder to water at $43^{\circ} \mathrm{C}$ and mixing thoroughly with a wire whisk. Milk replacer was fed to calves in open buckets. Calves were gradually weaned

Table 3. Calf starter composition on a DM basis.

\begin{tabular}{lcr}
\hline & $\begin{array}{l}\text { Low (L) or } \\
\text { moderate (M) } \\
\text { diet }^{1}\end{array}$ & $\begin{array}{l}\text { High (H) } \\
\text { diet }^{2}\end{array}$ \\
\hline Cariable $\%$ & 20.5 & 25.0 \\
Crude fat, \% & 3.4 & 3.4 \\
Crude fiber, \% & 7.95 & 9.0 \\
ADF, \% & 9.0 & 12.5 \\
Ca, \% & 0.51 & 0.51 \\
Ca maximum, \% & 1.02 & 1.02 \\
P, \% & 0.51 & 0.51 \\
Salt minimum, \% & 0.40 & 0.45 \\
Salt maximum, \% & 0.57 & 0.68 \\
Se, ppm & 0.3 & 0.3 \\
Vitamin A, IU/kg & 48,510 & 24,917 \\
\hline
\end{tabular}

${ }^{1}$ Gold Flake Calf Starter (Nutrena Feeds, Winnipeg, Manitoba, Canada) (guaranteed analysis). Estimated energy density was 3.6 Mcal of ME $/ \mathrm{kg}$ of DM. $\mathrm{L}=$ low protein and energy intake; $\mathrm{M}=$ moderate protein and energy intake.

${ }^{2}$ Herd Builder Calf Starter (Nutrena Feeds) (guaranteed analysis), with protein balanced for amino acid needs of young calves. Estimated energy density was $3.7 \mathrm{Mcal}$ of $\mathrm{ME} / \mathrm{kg}$ of $\mathrm{DM}$. $\mathrm{H}=$ high protein and energy intake. 
from milk replacer by 7 wk of age by reducing the amount of milk offered per day to $50 \%$ on $d-3,25 \%$ on $\mathrm{d}-2$, and $12.5 \%$ on $\mathrm{d}-1$ before weaning on $\mathrm{d} 0$.

From 8 to 14 wk of age, calves on the low $\operatorname{diet}(\mathbf{L}$; low protein and energy intake) were fed grain at restricted intake to achieve $0.4 \mathrm{~kg}$ of $\mathrm{ADG}$, whereas calves on the $\mathrm{H}$ diet were fed high-protein grain for ad libitum intake. From 8 to 9 wk of age, calves were fed the respective calf starters, but beginning at 9 wk of age, rolled corn was added to both diets to determine the potential for increased corn utilization in the diet. The new diets contained $70 \%$ of the respective calf starters and $30 \%$ rolled corn. According to laboratory analyses, nutrient values for corn were $7.8 \% \mathrm{CP}$ and $3.75 \%$ crude fat, and the new grain mixes were $16.5 \% \mathrm{CP}$ and $3.8 \%$ crude fat for the L diet and $21.3 \% \mathrm{CP}$ and $3.7 \%$ crude fat for the $\mathrm{H}$ diet. Calves had fresh water available ad libitum.

Calves were weighed on 2 consecutive days, and withers height was measured on the first day of each experimental week. At each feeding, refusals of milk replacer and calf starter were weighed and recorded. Amount of milk replacer offered was adjusted based on weekly BW. Calves were allowed 30 min to drink milk replacer or until interest in drinking was no longer evident. During the second period, amounts of grain offered were adjusted using equations of the NRC (2001) and weekly BW of calves fed diet $L$ to achieve the desired net energy intake for the target ADG of $400 \mathrm{~g} / \mathrm{d}$. During the second period, calves fed the $\mathrm{H}$ diet were provided the grain mix for ad libitum consumption to achieve a minimum ADG of $1000 \mathrm{~g} / \mathrm{d}$. Starter orts were weighed before the next feeding of starter.

\section{Blood Collection and Analyses}

Seventy-two hours after arrival, a single blood sample was collected from the jugular vein of each calf for measurement of IgG concentrations in serum as an indicator of passive immunity. Serum was harvested by centrifugation of samples at $1550 \times g$ for $20 \mathrm{~min}$ and used in a radial immunodiffusion assay to measure concentrations of IgG (VMRD, Inc., Pullman, WA). No differences in initial concentrations of IgG were detected among calves on the 4 treatments, with an overall mean of $10 \mathrm{mg} / \mathrm{mL}$.

Beginning at 2 wk of age, blood samples were collected from a jugular vein of each calf once weekly. The anticoagulant used was EDTA. Plasma was recovered by centrifugation at $1550 \times \mathrm{g}$ for $20 \mathrm{~min}$ and frozen at $-20^{\circ} \mathrm{C}$ for later analysis.

Insulin-like growth factor-I concentrations in plasma samples were determined by radioimmunoassay after removal of binding proteins by using an acid-ethanol extraction (Sharma et al., 1994). Recombinant human
IGF-I and the primary antibody were obtained from GroPep (Adelaide, Australia). Leptin concentrations in plasma samples were determined at the University of Missouri using a double-antibody radioimmunoassay (Delavaud et al., 2000).

\section{Slaughter Procedure}

Calves were slaughtered at 8 or 14 wk of age. One set of calves ( 1 or 2 calves from each block; $n=5$ calves on $\operatorname{diet} \mathrm{M} ; \mathrm{n}=6$ calves on $\operatorname{diet} \mathrm{H}$ ) was selected randomly and slaughtered at $8 \mathrm{wk}$ of age to assess body composition after period 1 . The remaining 41 calves were slaughtered at 14 wk of age.

Calves were weighed during the afternoon of the day before slaughter. Calves were then fed and allowed 1 $\mathrm{h}$ to eat prior to being shipped to the Michigan State University Meats Laboratory at $1630 \mathrm{~h}$. Calves were weighed again immediately before slaughter, approximately 14 to $16 \mathrm{~h}$ after last feeding. The calves were slaughtered using captive bolt stunning followed by exsanguination.

\section{Carcass Composition and Analyses}

The hide, head, legs, and tail were removed before the carcass was split into halves, weighed, and chilled for $24 \mathrm{~h}$. The left half of the carcass was ground 3 times through a commercial grinder (Autio Company, Astoria, OR). Subsamples were obtained and frozen at $-20^{\circ} \mathrm{C}$. Samples were ground to a powder using liquid nitrogen in a Waring Blender (Waring Products Division, New Hartford, CT). Dry matter was determined by the difference from wet weight after the sample was placed in an oven at $105^{\circ} \mathrm{C}$ for $24 \mathrm{~h}$. Ash was determined after a 5 -h oxidation in a muffle furnace at $500^{\circ} \mathrm{C}$. Crude protein was analyzed according to Hach et al. (1987). Fat was determined by Soxhlet ether extraction (AOAC, 1990).

\section{Statistical Analyses}

Growth and carcass traits for period 1 were analyzed as a one-factor ANOVA with $\mathrm{M}$ and $\mathrm{H}$ diets as the treatments and date of purchase as the blocks. Growth traits for period 1 included all heifers slaughtered at 8 and $14 \mathrm{wk}$. Growth and carcass traits for period 2 were analyzed as a $2 \times 2$ factorial experiment with diets fed during period 1 ( 2 to $8 \mathrm{wk}$ of age) by the diets fed during period 2 ( 8 to $14 \mathrm{wk}$ of age). Data were analyzed using the general linear models procedure of SAS 8.2 (SAS Institute Inc., Cary, NC) with date of purchase as the block. A repeated measure analysis (PROC MIXED in SAS) that modeled correlated residuals within heifer 


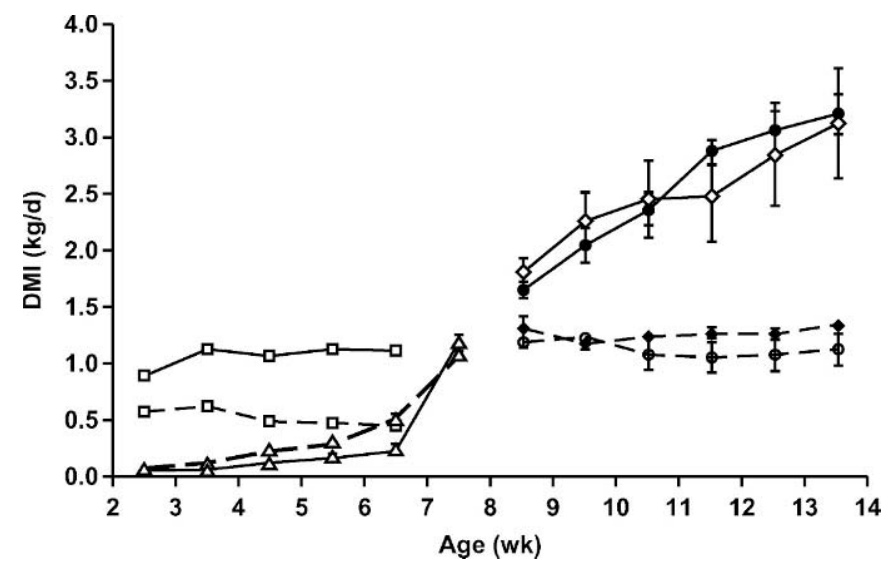

Figure 1. Weekly DMI. Abbreviations represent intake of milk replacer $(\square)$ and starter $(\triangle)$ by calves on either the moderate (moderate energy and protein intake) (M; ----) or high (high energy and protein intake) $(\mathrm{H} ;-$ ) diet during period 1 and intake of starter by calves on either the $\mathrm{M}$ or $\mathrm{H}$ diet during period 1 and the low (L; low energy and protein intake) or $\mathrm{H}$ diet during period 2: $\mathrm{HH}(-\diamond-)$, HL (----), MH (-—), ML (--○--). Calves were weaned from milk replacer by 7 wk of age. Data are presented as means \pm SEM.

(Littell et al., 1996) was used to analyze plasma IGFI, leptin, and fecal scores within period. Concentrations of IGF-I were log transformed before analysis.

\section{RESULTS}

\section{Growth and Body Composition}

The $\mathrm{H}$ diet increased DMI (Figure 1; Tables 4 and 5) and ADG $(P<0.001$; Figures $2 \mathrm{~A}$ and $3 \mathrm{~A}$; Tables 4 and 5 ), compared with the $M$ diet during period 1 or the $L$ diet during period 2. At 8 wk of age, calves fed the $\mathrm{H}$ diet during the first period had greater withers heights $(P<0.01)$ than calves on the $\mathrm{M}$ diet. Calves on the $\mathrm{H}$ diet during the second period were taller $(P=0.001)$ than calves on the $\mathrm{L}$ diet. No interaction $(P=0.8)$ of the two periods was detected for withers height.

Calves consuming the $\mathrm{H}$ diet in period 1 had greater gain:feed ratios than calves fed the M diet (Table 4). No interaction $(P=0.56)$ of diets was detected for gain:feed ratio during the 2 periods (Table 5). A tendency $(P=$ 0.08 ) was detected for an interaction of diets during the 2 periods for daily DMI (Table 5). That is, calves fed the $\mathrm{H}$ diet in period 2 tended to have greater DMI when they were fed the $\mathrm{H}$ diet in period 1 , possibly as a result of larger body size.

Effects of diet on carcass composition were significant only in the calves slaughtered at $14 \mathrm{wk}$ of age. Carcass weight at slaughter was greater for calves consuming the $\mathrm{H}$ diet during either period $1(P=0.06)$ or period $2(P<0.001)$. Carcass dressing percentage (hot carcass weight as a percentage of live weight at slaughter) at 8 wk of age was not significantly affected by treatment (Table 6). However, in calves slaughtered at $14 \mathrm{wk}$ of age, carcass dressing percentage was greater for calves fed the $\mathrm{H}$ diet during both periods $(P<0.02$ and $P<$ 0.001, respectively; Table 7). Carcass protein percentage was not affected by diet in either period. The $\mathrm{H}$ diet in the second period, however, increased $(P<0.001)$ carcass fat percentage. Carcass water percentage was not affected by diet in the first period. In the second period, calves fed ML (M diet during period 1 and $\mathrm{L}$ diet during period 2) and HL (H diet during period 1 and $\mathrm{L}$ diet during period 2$)$ had a greater $(P=0.02)$ percentage of water than $\mathrm{MH}$ ( $\mathrm{M}$ diet during period 1 and $\mathrm{H}$ diet during period 2) or $\mathrm{HH}$ ( $\mathrm{H}$ diet during period 1 and $\mathrm{H}$ diet during period 2) calves. Carcass ash percentage was not affected by treatment.

\section{Health}

For the calves that finished period 1 , those fed the $\mathrm{H}$ diet had higher fecal scores in the first 2 wk of period 1 compared with those fed the $\mathrm{M}$ diet $(\mathrm{H}$ diet $=3.25$; $\mathrm{M}$ diet $=2.86 ; P<0.001$ ). Fecal scores declined (feces became drier) from d 2 through 14 of period $1(P<0.001)$. No interaction of treatment and day was detected $(P=$ $0.11)$. Rates of mortality for the calves on various diets did not differ ( $\mathrm{H}$ diet $=5$ of $33 ; \mathrm{M}$ diet $=5$ of 32 ). Compared with calves having lower fecal scores $(<4)$,

Table 4. Least square means for body growth variables during period 1.

\begin{tabular}{lllll}
\hline Trait & Moderate diet $^{1}$ & High diet $^{1}$ & SEM & $P>F$ \\
\hline & $(\mathrm{n}=26)$ & $(\mathrm{n}=26)$ & & \\
Initial BW at 2 wk, kg & 44.1 & 44.0 & 0.9 & 0.98 \\
BW at 8 wk, kg & 60.0 & 72.1 & 1.5 & 0.001 \\
Initial withers height at 2 wk, cm & 77.4 & 78.1 & 0.6 & 0.45 \\
Height at 8 wk, cm & 83.5 & 85.9 & 0.6 & 0.01 \\
ADG, kg/d & 0.379 & 0.668 & 0.02 & 0.001 \\
Daily milk powder DMI, kg & 0.434 & 0.878 & 0.02 & 0.001 \\
Daily starter DMI, kg & 0.413 & 0.335 & 0.02 & 0.001 \\
Total DMI, kg/d & 0.847 & 1.213 & 0.03 & 0.001 \\
Gain:feed & 0.439 & 0.550 & 0.01 & 0.001 \\
\hline
\end{tabular}

${ }^{1}$ Moderate $=$ moderate protein and energy intake; high = high protein and energy intake. 
Table 5. Least square means for body growth in period 2 with residual effects of period $1 .^{1}$

\begin{tabular}{|c|c|c|c|c|c|c|c|c|}
\hline \multirow[b]{4}{*}{ Variable } & \multicolumn{4}{|c|}{ Period 1} & \multirow{3}{*}{\multicolumn{4}{|c|}{$P>F$}} \\
\hline & \multicolumn{2}{|c|}{ Moderate (M) diet } & \multicolumn{2}{|c|}{ High $(\mathrm{H})$ diet } & & & & \\
\hline & \multicolumn{4}{|c|}{ Period 2} & & & & \\
\hline & $\begin{array}{l}\text { Low (L) } \\
\text { diet } \\
(\mathrm{n}=11)\end{array}$ & $\begin{array}{l}\mathrm{H} \text { diet } \\
(\mathrm{n}=10)\end{array}$ & $\begin{array}{l}\mathrm{L} \text { diet } \\
(\mathrm{n}=9)\end{array}$ & $\begin{array}{l}\mathrm{H} \text { diet } \\
(\mathrm{n}=11)\end{array}$ & $\mathrm{SEM}^{2}$ & Period 1 & Period 2 & $\begin{array}{l}\text { Period } 1 \\
\text { diet } \times \\
\text { period } 2 \text { diet }\end{array}$ \\
\hline BW at $14 \mathrm{wk}, \mathrm{kg}$ & 79.7 & 106.3 & 87.3 & 120.6 & 3.4 & 0.002 & 0.001 & 0.30 \\
\hline Height at $14 \mathrm{wk}, \mathrm{cm}$ & 88.1 & 91.8 & 90.4 & 94.6 & 1.2 & 0.03 & 0.001 & 0.81 \\
\hline $\mathrm{ADG}, \mathrm{kg} / \mathrm{d}$ & 0.47 & 1.06 & 0.40 & 1.13 & 0.05 & 0.99 & 0.001 & 0.12 \\
\hline Daily DMI, kg & 1.29 & 2.61 & 1.29 & 3.02 & 0.11 & 0.08 & 0.001 & 0.08 \\
\hline Gain:feed & 0.37 & 0.41 & 0.32 & 0.37 & 0.02 & 0.02 & 0.02 & 0.56 \\
\hline
\end{tabular}

${ }^{1} \mathrm{M}=$ Moderate protein and energy intake, $\mathrm{H}=$ high protein and energy intake, and $\mathrm{L}=$ low protein and energy intake.

${ }^{2}$ Largest standard error reported.

calves with higher fecal scores $(\geq 4)$ were more likely to die $(P<0.001)$.

\section{Hormones}

Within a period, plasma concentrations of IGF-I were greater $(P<0.001)$ for calves fed the $\mathrm{H}$ diet than for those fed the $\mathrm{M}$ or L diets (Figures $2 \mathrm{~B}$ and $3 \mathrm{~B}$ ). Concentrations of plasma IGF-I in calves fed the $\mathrm{H}$ diet in period 1 declined at weaning (Figure 2B) but, at $8 \mathrm{wk}$, continued to differ from calves fed the $\mathrm{M}$ diet.

Plasma concentrations of leptin were greater $(P=$ 0.03) for calves fed the $\mathrm{H}$ diet than for calves fed the $\mathrm{M}$ diet in period 1 before weaning (Figure 2C). Treatment did not affect plasma concentrations of leptin during period 2 (Figure $3 \mathrm{C}$ ).

\section{Costs}

Costs of milk replacer consumed were greater $(P=$ $0.001)$ for calves fed the $\mathrm{H}$ diet than for calves fed the $\mathrm{M}$ diet (Table 8). Costs of starter consumed during period 1 were not different; however, costs of starter consumed during period 2 were greater $(P=0.001)$ for calves fed the $\mathrm{H}$ diet. Feed costs per kilogram of $\mathrm{BW}$ gain of calves fed the $\mathrm{M}$ or $\mathrm{L}$ and $\mathrm{H}$ diets were not different in periods 1 or 2 .

\section{DISCUSSION}

Previous reports demonstrated that a high feeding level increased ADG of heifer calves before weaning (Foldager and Krohn, 1994; Bar-Peled et al., 1997; Sejrsen et al., 1998). In the Israeli and Danish studies, calves either were suckled or fed whole milk rather than milk replacer, which is typically fed by US dairy producers for at least a portion of the preweaning period
(Heinrichs et al., 1994). Results of our study show that increased energy and protein intake by heifer calves consuming milk replacer can increase rate of $\mathrm{BW}$ gain and withers height. Based on DMI for the $\mathrm{H}$ diet and NRC (2001) recommendations, these calves were expected to gain 800 to $1000 \mathrm{~g} / \mathrm{d}$ during period 1 . However, calves fed the $\mathrm{H}$ diet did not achieve their targeted rate of gain during period 1, possibly because of poor passive immunity. Actual ADG before weaning was $760 \mathrm{~g} / \mathrm{d}$. Results from other studies that began intensive feeding at an early age (Foldager and Krohn, 1994; Bar-Peled et al., 1997; Sejrsen et al., 1998) indicated that there may be benefits in beginning the intensive feeding at birth to achieve greater rates of gain by weaning. Calves consuming the $\mathrm{H}$ diet during the first period also experienced reduced growth rates after weaning, a problem that might have been alleviated by a more gradual weaning process than was used in this experiment.

Because $50 \%$ of withers height increase occurs in the first 6 mo of life (Kertz et al., 1998), we anticipated that the calves fed the $\mathrm{H}$ diet would gain faster than calves fed the M or L diets in both BW and frame size. At the outset, all calves were similar in withers height. At the end of both periods, calves fed the $\mathrm{H}$ diet were taller. Final mature height is determined by genetic potential, but diet and feeding regimen can result in animals achieving that genetic potential earlier or being retarded in growth and never achieving their maximal mature size (Owens et al., 1993). Thus, calves fed the $\mathrm{H}$ diet may have the potential to achieve structural maturity at a younger age.

In both periods, feed efficiency was greater for calves fed the $\mathrm{H}$ diet than for calves fed the $\mathrm{M}$ or $\mathrm{L}$ diets. Similarly, calves consuming $2.43 \%$ of their BW on a DM basis gained $>0.9 \mathrm{~kg} / \mathrm{d}$ and were more efficient in converting feed to gain compared with calves consuming 1.38 to $2 \%$ of their $\mathrm{BW}$ on a $\mathrm{DM}$ basis during the 
A
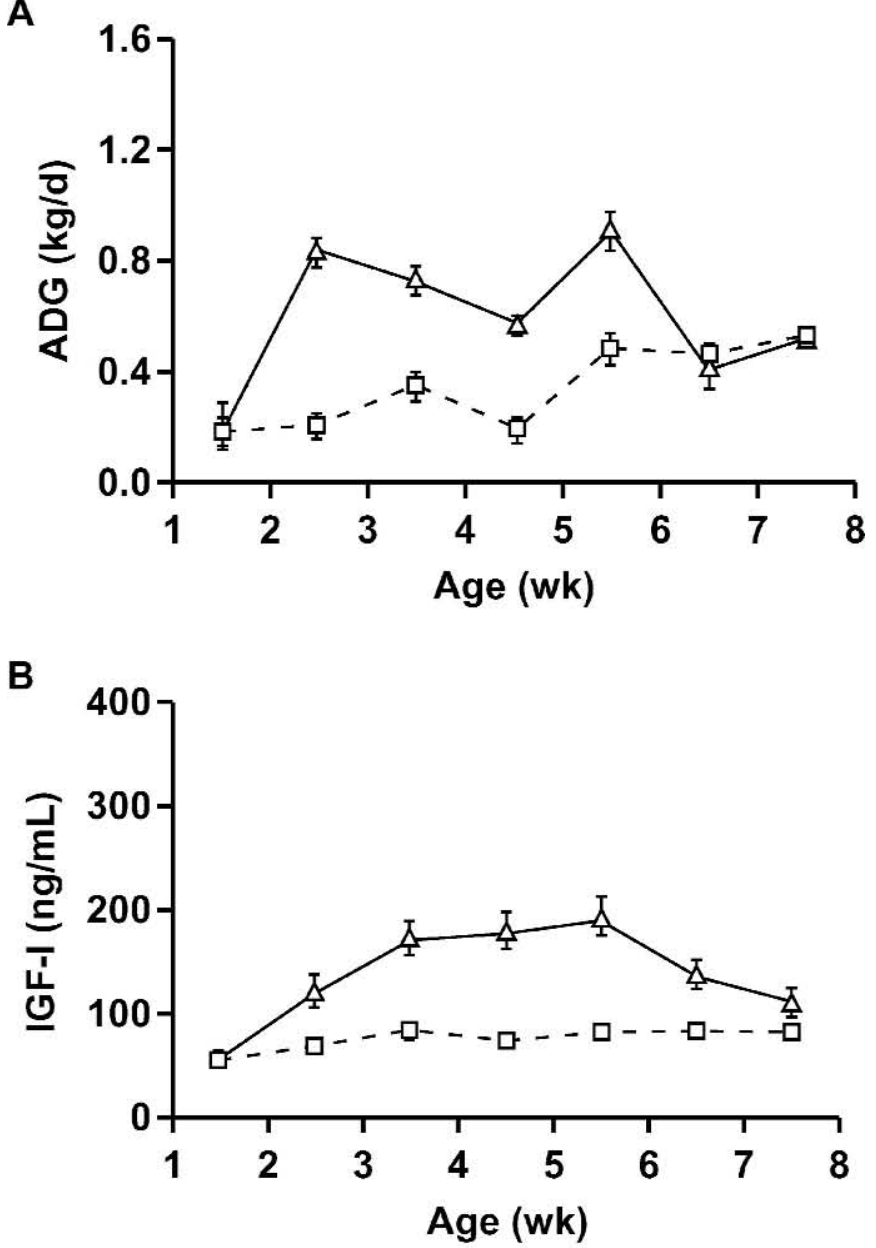

C

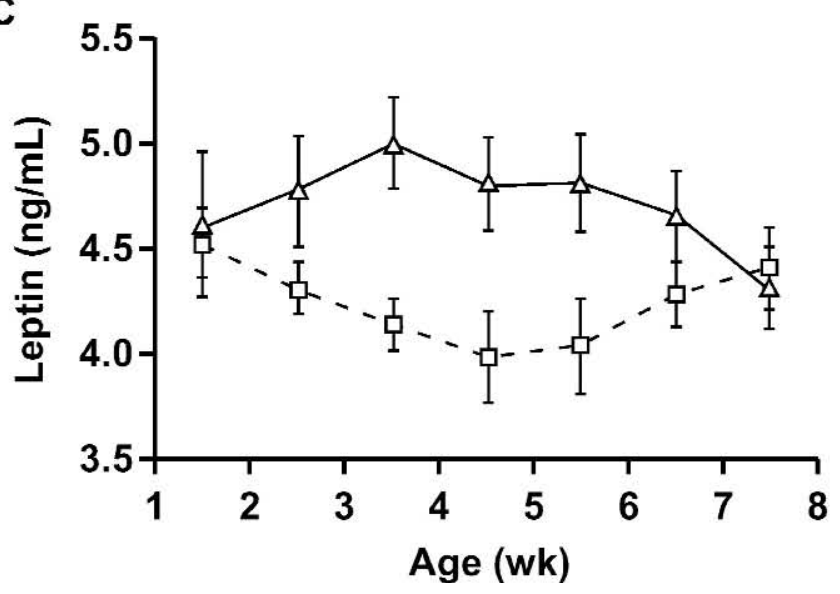

Figure 2. Weekly ADG (A), plasma IGF-I (B), and plasma leptin (C) in calves on high (high protein and energy intake) $(-\triangle-)$ or moderate (moderate protein and energy intake) (-- $\square--)$ diets for each week during period 1 (2 to 8 wk of age) of the experiment. Data are presented as means \pm SEM.
A

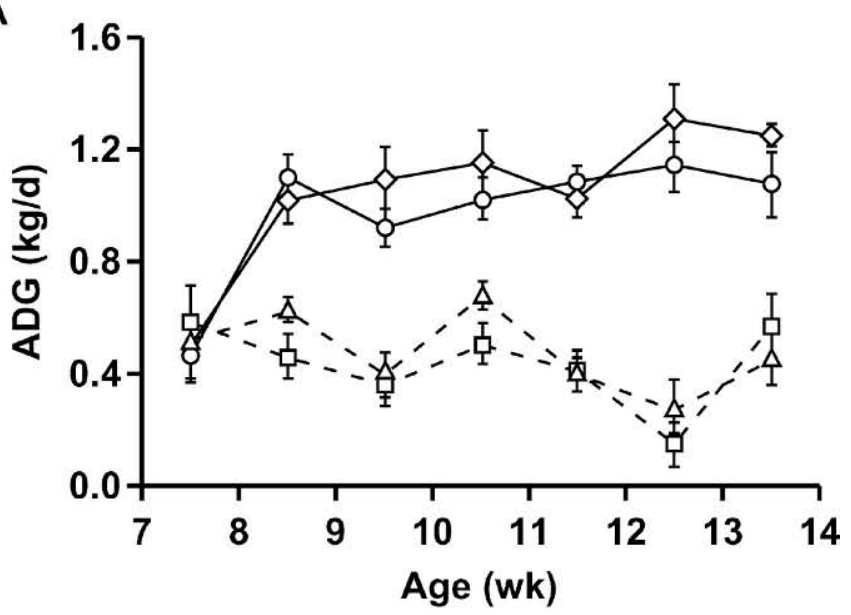

B

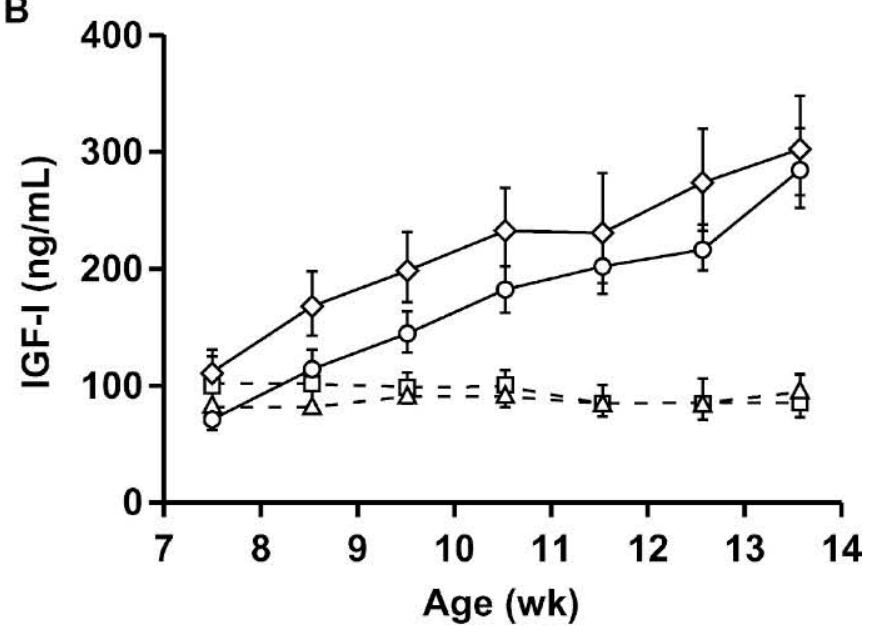

C

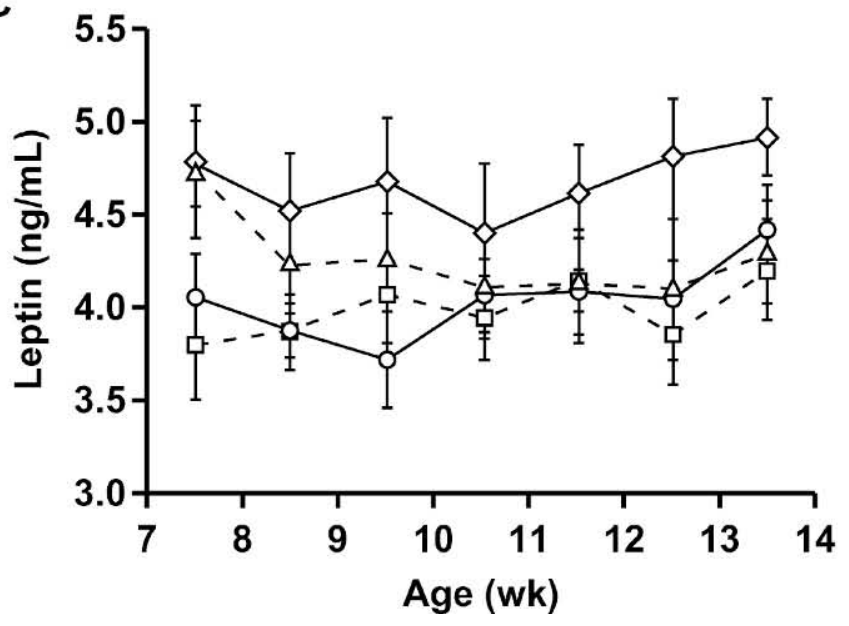

Figure 3. Weekly ADG (A), plasma IGF-I (B), and plasma leptin (C) in calves on either the low (L; low protein and energy intake) or high $(\mathrm{H}$; high energy and protein intake) diet during each week of period 2 of the experiment. Abbreviations represent either the $\mathrm{M}$ (moderate; moderate protein and energy intake) or $\mathrm{H}$ diet during period 1 and the $\mathrm{L}$ or $\mathrm{H}$ diet during period 2: $\mathrm{HH}(-\diamond-)$, HL $(--\square--)$, MH (-○—), MM (-- $\triangle--)$. Data are presented as means \pm SEM. 
Table 6. Least square means for carcass composition of calves slaughtered at end of period 1 at 8 wk of age. ${ }^{1}$

\begin{tabular}{lcccc}
\hline & $\begin{array}{l}\text { Moderate } \\
\text { diet } \\
(\mathrm{n}=5)\end{array}$ & $\begin{array}{l}\text { High diet } \\
(\mathrm{n}=6)\end{array}$ & $\mathrm{SEM}^{2}$ & $P>F$ \\
Carcass trait & 29.5 & 38.0 & 2.7 & 0.06 \\
\hline Weight, kg & 53.3 & 54.5 & .06 & 0.15 \\
Weight, \% of live weight & 19.8 & 19.9 & 0.7 & 0.92 \\
Protein, \% & 4.4 & 5.2 & 0.5 & 0.24 \\
Fat, \% & 71.4 & 70.9 & 1.1 & 0.76 \\
Water, \% & 4.4 & 4.3 & 0.4 & 0.85 \\
Ash, \%
\end{tabular}

${ }^{1}$ Moderate $=$ moderate protein and energy intake; high = high protein and energy intake.

${ }^{2}$ Largest standard error reported.

first 6 wk of life (Khouri and Pickering, 1968). The H diet from 8 to 14 wk increased carcass weight and carcass dressing percentages. Previous work (Tikofsky et al., 2001) demonstrated that calves raised on milkbased diets having a high fat content deposited more body fat than calves consuming lower levels of fat. Further, they showed that fat levels $>15 \%$ were not beneficial for lean mass deposition. Carcass fat did not differ between calves fed the $\mathrm{M}$ and $\mathrm{H}$ diets up to 8 wk of age. However, calves fed the $\mathrm{H}$ diet from 8 to 14 wk had more carcass fat, indicating that the $\mathrm{H}$ diet did not promote the observed rate of gain $(>1 \mathrm{~kg} / \mathrm{d})$ without a concomitant increase in body fat deposition.

Fecal scores were higher for calves fed the $\mathrm{H}$ diet during the first period. Other studies have shown increased incidence of diarrhea in calves consuming diets higher in carbohydrate content (Lister and Lodge, 1973; Lodge and Lister, 1973), although the higher fecal scores observed in our calves did not equate to an apparent depression in health. Treatment did not affect mor- tality in this study, in contrast to a previous report in which calves on a lower intake of milk replacer had greater mortality than calves on a high intake diet (Williams et al., 1981).

Normal postnatal growth is regulated in part by IGFI, a mediator of somatotropin actions in many body tissues. The importance of circulating IGF-I, which originates primarily from the liver (Yakar et al., 1999), to growth is not known (LeRoith et al., 2001), but its concentrations are influenced by nutrition (Thissen et al., 1994) as well as birth weight and age (Breier et al., 1988; Hammon and Blum, 1997). Perhaps nutritional factors regulate the pool of circulating IGF-I available to tissues and its subsequent biological effects through actions on the IGF-binding proteins (Ketelslegers et al., 1996). Relative to nutrient restriction, however, overnutrition is a less potent regulator of concentrations of circulating IGF-I (Thissen et al., 1994).

Plasma IGF-I concentrations in our calves averaged $50 \mathrm{ng} / \mathrm{mL}$ at 2 wk of age, confirming earlier reports (Breier et al., 1988; Smith et al., 2002). Effects of age and nutrient intake on IGF-I cannot be distinguished, because positive correlations exist among ADG, BW, and serum IGF-I concentrations (Kerr et al., 1991; Nosbush et al., 1996). As expected, however, calves fed the $\mathrm{H}$ diet had greater plasma concentrations of IGF-I than did calves fed the $\mathrm{M}$ or L diets during both periods. As BW increased, plasma IGF-I concentrations also increased in male calves at 3 different $\mathrm{BW}$, but having similar ADG (Smith et al., 2002). Further, Smith et al. (2002) showed that at similar BW, as ADG increased, concentrations of IGF-I increased. Petitclerc et al. (1999) determined that heifer calves allowed ad libitum intake had greater concentrations of IGF-I, and Bartlett (2001) reported greater plasma IGF-I concentrations in

Table 7. Least square means for carcass composition of calves slaughtered at the end of period 2 at $14 \mathrm{wk}$ of age. ${ }^{1}$

\begin{tabular}{|c|c|c|c|c|c|c|c|c|}
\hline \multirow[b]{4}{*}{ Carcass trait } & \multicolumn{4}{|c|}{ Period 1} & \multirow[b]{4}{*}{$\mathrm{SEM}^{2}$} & \multirow{3}{*}{\multicolumn{3}{|c|}{$\mathrm{P}>\mathrm{F}$}} \\
\hline & Moderat & (M) diet & High & H) diet & & & & \\
\hline & \multicolumn{4}{|c|}{ Period 2} & & & & \\
\hline & $\begin{array}{l}\text { Low }(\mathrm{L}) \\
\text { diet } \\
(\mathrm{n}=11)\end{array}$ & $\begin{array}{l}\mathrm{H} \text { diet } \\
(\mathrm{n}=10)\end{array}$ & $\begin{array}{l}\mathrm{L} \text { diet } \\
(\mathrm{n}=9)\end{array}$ & $\begin{array}{l}\mathrm{H} \text { diet } \\
(\mathrm{n}=11)\end{array}$ & & Period 1 & Period 2 & $\begin{array}{l}\text { Period } 1 \\
\text { diet } \times \\
\text { period } 2 \text { diet }\end{array}$ \\
\hline $\begin{array}{l}\text { Weight, } \mathrm{kg} \\
\text { Weight, \% of }\end{array}$ & 37.8 & 52.0 & 41.9 & 62.1 & 1.8 & 0.001 & 0.001 & 0.10 \\
\hline live weight & 49.4 & 51.4 & 50.0 & 54.2 & 0.7 & 0.02 & 0.001 & 0.11 \\
\hline Protein, \% & 20.3 & 19.3 & 20.4 & 20.3 & 0.6 & 0.33 & 0.29 & 0.41 \\
\hline Fat, \% & 4.5 & 7.2 & 5.8 & 7.6 & 0.5 & 0.06 & 0.001 & 0.32 \\
\hline Water, \% & 70.1 & 68.0 & 68.6 & 67.5 & 0.6 & 0.12 & 0.02 & 0.43 \\
\hline Ash, \% & 4.4 & 5.1 & 5.1 & 4.4 & 0.3 & 0.97 & 0.90 & 0.03 \\
\hline
\end{tabular}


Table 8. Costs for milk replacer and starter consumed during periods 1 and $2 .{ }^{1}$

\begin{tabular}{|c|c|c|c|c|c|c|c|c|}
\hline \multirow[b]{3}{*}{ Variable } & \multicolumn{4}{|c|}{ Period 1} & \multirow[b]{3}{*}{$\mathrm{SEM}^{2}$} & \multirow{2}{*}{\multicolumn{3}{|c|}{$\mathrm{P}>\mathrm{F}$}} \\
\hline & \multicolumn{4}{|c|}{ Period 2} & & & & \\
\hline & $\begin{array}{l}\text { Low (L) } \\
\text { diet } \\
(\mathrm{n}=11)\end{array}$ & $\begin{array}{l}\mathrm{H} \text { diet } \\
(\mathrm{n}=10)\end{array}$ & $\begin{array}{l}\mathrm{L} \text { diet } \\
(\mathrm{n}=9)\end{array}$ & $\begin{array}{l}\mathrm{H} \text { diet } \\
(\mathrm{n}=11)\end{array}$ & & Period 1 & Period 2 & $\begin{array}{l}\text { Period } 1 \\
\text { diet } \times \\
\text { period } 2 \text { diet }\end{array}$ \\
\hline $\begin{array}{l}\text { Feed cost/gain, period } 1, \\
\$ / \mathrm{kg} \text { gain }\end{array}$ & 2.41 & 2.89 & 3.01 & 2.73 & 0.28 & 0.43 & & \\
\hline Starter, period $2, \$$ & 15.14 & 35.23 & 15.17 & 40.74 & 1.59 & 0.08 & 0.001 & 0.08 \\
\hline $\begin{array}{l}\text { Feed cost/gain, period } 2, \\
\$ / \mathrm{kg} \text { gain }\end{array}$ & 0.78 & 0.80 & 0.92 & 0.88 & 0.06 & 0.03 & 0.82 & 0.54 \\
\hline
\end{tabular}

${ }^{1} \mathrm{M}=$ moderate protein and energy intake, $\mathrm{H}=$ high protein and energy intake, and $\mathrm{L}=$ low protein and energy intake.

${ }^{2}$ Largest standard error reported

response to a higher feeding rate and to higher dietary CP concentration. At weaning, IGF-I concentrations in animals in the former study decreased by $100 \mathrm{ng} / \mathrm{mL}$. Similarly, treatment differences in IGF-I concentrations in our study were no longer evident during the first period after weaning of calves, likely because of the post-weaning depression in growth rates noted in calves fed the $\mathrm{H}$ diet.

Leptin is synthesized and secreted primarily in adipose tissue, in addition to multiple other sites of production including the mammary gland (Smith and Sheffield, 2002). It is regulated by multiple hormones including somatotropin, insulin, and IGF-I (Houseknecht et al., 2000; Smith and Sheffield, 2002), with plasma concentrations directly related to the degree of adiposity (Ehrhardt et al., 2000). Leptin has a major role in appetite regulation as well as a variety of other effects in the body (Fruhbeck, 2001), most of which have been studied in adult animals. Little is known about the importance of leptin in the early postnatal period, despite its potential role in important processes such as mammary development (Silva et al., 2002). Block et al. (2003) demonstrated that plasma leptin concentrations in dairy bull calves are influenced by nutrition within the first few weeks of life. Similarly, calves fed the $\mathrm{H}$ diet during period 1 of the current experiment had greater serum leptin concentrations than calves fed the $\mathrm{M}$ diet by $4 \mathrm{wk}$ of age. Differences, however, were no longer evident after weaning or during period 2, possibly because treatment differences in body fat percentage after weaning were not sufficient to elicit differences in plasma leptin.

The $\mathrm{H}$ diet cost more than the $\mathrm{M}$ or $\mathrm{L}$ diets as a result of the increased amount of milk replacer and grain offered to calves. In addition, feedstuffs for the $\mathrm{H}$ diet contained more protein, making them more costly.
Kertz et al. (1998) observed that cost per kg of BW gain and cost per $\mathrm{cm}$ of height gain was least in the first 6 mo of life. Although the $\mathrm{H}$ diet was more costly, the rate of BW gain was increased, resulting in similar feed costs per unit of gain. Thus, the $\mathrm{H}$ diet has the potential to promote puberty and first calving at a younger age without increasing feed costs.

\section{CONCLUSIONS}

Calves consuming increased amounts of energy and protein had greater rates of gain with greater feed efficiencies during the periods from 2 to $8 \mathrm{wk}$ of age and from 8 to $14 \mathrm{wk}$ of age. Increased energy and protein intake from 2 to $8 \mathrm{wk}$ of age did not alter carcass composition, demonstrating the usefulness of the $\mathrm{H}$ diet for increasing growth rates without encouraging deposition of body fat. To achieve younger ages at puberty and first calving in dairy heifers, the preweaning period offers potential to increase body growth rates through increased energy and protein intake without causing excess fattening.

\section{ACKNOWLEDGMENTS}

We are grateful to Milk Specialties Inc. for generous provision of milk replacer, and Troy Scott, Dan Grooms, and Mike Van Amburgh for valuable input.

\section{REFERENCES}

Association of Official Analytical Chemists International. 1990. Official Methods of Analysis. Vol. I. 15th ed. AOAC, Arlington, VA. Bar-Peled, U., B. Robinzon, E. Maltz, H. Tagari, Y. Folman, I. Bruckental, H. Voet, H. Gacitua, and A. R. Lehrer. 1997. Increased weight gain and effects on production parameters of Holstein heifer calves that were allowed to suckle from birth to six weeks of age. J. Dairy Sci. 80:2523-2528. 
Bartlett, K. S. 2001. Interactions of protein and energy supply from milk replacers on growth and body composition of dairy calves. J. Dairy Sci. 86:3206-3214.

Block, S. S., J. M. Smith, R. A. Ehrhardt, M. C. Diaz, R. P. Rhoads, M. E. Van Amburgh, and Y. R. Boisclair. 2003. Nutritional and developmental regulation of plasma leptin in dairy cattle. J. Dairy Sci. 86:3206-3214.

Blome, R. M., J. K. Drackley, F. K. McKeith, M. F. Hutjens, and G. C. McCoy. 2003. Growth, nutrient utilization, and body composition of dairy calves fed milk replacers containing different amounts of protein. J. Anim. Sci. 81:1641-1655.

Breier, B. H., P. D. Gluckman, and J. J. Bass. 1988. Plasma concentrations of insulin-like growth factor-I and insulin in the infant calf: Ontogeny and influence of altered nutrition. J. Endocrinol. 119:43-50.

Brown, E. G., M. J. VandeHaar, K. M. Daniels, J. S. Liesman, L. T. Chapin, J. W. Forrest, R. M. Akers, R. E. Pearson, and M. S. Weber Nielsen. 2005. Effect of increasing energy and protein intake on mammary development in heifer calves. J. Dairy Sci. 88:595-603.

Delavaud, C., F. Bocquier, Y. Chilliard, D. H. Keisler, A. Gertler, and G. Kann. 2000. Plasma leptin concentrations in ruminants: Effect of nutritional status and body fatness on plasma leptin concentration assessed by a specific RIA in sheep. J. Endocrinol. 165:519-526.

Diaz, M. C., M. E. Van Amburgh, J. M. Smith, J. M. Kelsey, and E. L. Hutten. 2001. Composition of growth of Holstein calves fed milk replacer from birth to 105 -kilogram body weight. J. Dairy Sci. 84:830-842.

Donnelly, P. E., and J. B. Hutton. 1976. Effects of dietary protein and energy on the growth of Friesian bull calves. II. Effects of level of feed intake and dietary protein content on body composition. N.Z. J. Agric. Res. 19:409-414.

Ehrhardt, R. A., R. M. Slepetis, J. Siegal-Willot, M. E. Van Amburgh, A. W. Bell, and Y. Boisclair. 2000. Development of a specific radioimmunoassay to measure physiological changes of circulating leptin in cattle and sheep. J. Endocrinol. 166:519-528.

Foldager, J., and C. C. Krohn. 1994. Heifer calves reared on very high or normal levels of whole milk from birth to 6-8 weeks of age and their subsequent milk production. Proc. Soc. Nutr. Physiol. 3:301. (Abstr.)

Fruhbeck, G. 2001. A heliocentric view of leptin. Proc. Nutr. Soc. 60:301-318

Hach, C. C., B. K. Bowden, A. B. Lopelove, and S. V. Brayton. 1987. More powerful peroxide Kjeldahl digestion method. J. AOAC 70:783-787.

Hammon, H., and J. W. Blum. 1997. The somatotropic axis in neonatal calves can be modulated by nutrition, growth hormone, and longR3-IGF-I. Am. J. Physiol. 273:E130--E138.

Heinrichs, A. J. 1993. Raising dairy replacements to meet the needs of the 21st century. J. Dairy Sci. 76:3179-3187.

Heinrichs, A. J., S. J. Wells, H. S. Hurd, G. W. Hill, and D. A. Dargatz 1994. The National Dairy Heifer Evaluation Project: A profile of heifer management practices in the United States. J. Dairy Sci. 77:1548-1555.

Houseknecht, K. L., C. P. Portocarrero, S. Ji, R. Lemenager, and M. E. Spurlock. 2000. Growth hormone regulates leptin gene expression in bovine adipose tissue: Correlation with adipose IGFI expression. J. Endocrinol. 164:51-57.

Kerr, D. E., B. Laarveld, M. I. Fehr, and J. G. Manns. 1991. Profiles of serum IGF-I in calves from birth to eighteen months of age and in cows throughout the lactation cycle. Can. J. Anim. Sci. 71:695-705.

Kertz, A. F., B. A. Barton, and L. F. Reutzel. 1998. Relative efficiencies of wither height and body weight increase from birth until first calving in Holstein cattle. J. Dairy Sci. 81:1479-1482.
Ketelslegers, J.-M., D. Maiter, M. Maes, L. E. Underwood, and J.-P. Thissen. 1996. Nutritional regulation of the growth hormone and insulin-like growth factor-binding proteins. Horm. Res. 45:252257.

Khouri, R. H., and F. S. Pickering. 1968. I. Performance of calves fed on different levels of whole milk relative to body weight. N.Z. J. Agric. Res. 11:227-236.

LeRoith, D., C. Bondy, S. Yakar, and J.-L. Liu. 2001. The somatomedin hypothesis: 2001. Endocr. Rev. 22:53-74.

Lister, E. E., and G. A. Lodge. 1973. Effects of increasing the energy value of a whole milk diet for calves. II. Growth, feed utilization and health. Can. J. Anim. Sci. 53:317-325.

Littell, R. C., G. A. Milliken, W. W. Stroup, and R. D. Wolfinger. 1996. SAS System for Mixed Models. SAS Institute, Inc., Cary, NC.

Lodge, G. A., and E. E. Lister. 1973. Effects of increasing the energy value of a whole milk diet for calves. I. Nutrient digestibility and nitrogen retention. Can. J. Anim. Sci. 53:307-316.

Nosbush, B. B., J. G. Linn, W. A. Eisenbeisz, J. E. Wheaton, and M. E. White. 1996. Effect of concentrate source and amount in diets on plasma hormone concentrations of prepubertal heifers. J. Dairy Sci. 79:1400-1409.

National Research Council. 2001. Pages 234-243 in Nutrient Requirements of Dairy Cattle. 7th rev.ed. Natl. Acad. Sci., Washington, DC.

Owens, F. N., P. Dubeski, and C. F. Hanson. 1993. Factors that alter the growth and development of ruminants. J. Anim. Sci. 71:3138-3150.

Petitclerc, D., P. Dumoulin, H. Ringuet, J. Matte, and C. Girard. 1999. Plane of nutrition and folic acid supplementation between birth and four months of age on mammary development of dairy heifers. Can. J. Anim. Sci. 79:227-234.

Sejrsen, K., and S. Purup. 1997. Influence of prepubertal feeding level on milk yield potential of dairy heifers: A review. J. Anim. Sci. 75:828-835.

Sejrsen, K., S. Purup, H. Martinussen, and M. Vestergaard. 1998. Effect of feeding level on mammary gland growth in calves and prepubertal heifers. J. Dairy Sci. 81(Suppl.1):377. (Abstr.)

Sharma, B. K., M. J. VandeHaar, and N. K. Ames. 1994. Expression of insulin-like growth factor-I in cows at different stages of lactation and in late lactation cows treated with somatotropin. J. Dairy Sci. 77:2232-2241.

Silva, L. F., M. J. VandeHaar, M. S. Weber Nielsen, and G. W. Smith. 2002. Evidence for a local effect of leptin in bovine mammary gland. J. Dairy Sci. 85:3277-3286.

Smith, J. L., and L. G. Sheffield. 2002. Production and regulation of leptin in bovine mammary epithelial cells. Domest. Anim. Endocrinol. 2:145-155.

Smith, J. M., M. E. Van Amburgh, M. C. Diaz, M. C. Lucy, and D. E. Bauman. 2002. Effect of nutrient intake on the development of the somatotropic axis and its responsiveness to GH in Holstein bull calves. J. Anim. Sci. 80:1528-1537.

Thissen, J.-P., J.-M. Ketelslegers, and L. E. Underwood. 1994. Nutritional regulation of the insulin-like growth factors. Endocr. Rev. 15:80-101.

Tikofsky, J. N., M. E. Van Amburgh, and D. A. Ross. 2001. Effect of varying carbohydrate and fat content of milk replacer on body composition of Holstein bull calves. J. Anim. Sci. 79:2260-2267.

Williams, P. E. V., D. Day, and A. M. Raven. 1981. The effect of climatic housing and level of nutrition on the performance of calves. Anim. Prod. 32:133-141.

Yakar, S., J.-L. Liu, B. Stannard, A. Butler, D. Accili, B. Sauer, and D. LeRoith. 1999. Normal growth and development in the absence of hepatic insulin-like growth factor I. Proc. Natl. Acad. Sci. USA 96:7324-7329. 